\title{
Rhodobacter capsulatus Gene Transfer Agent Transduction Assay
}

Molly M. Leung and John Thomas Beatty ${ }^{*}$

Department of Microbiology and Immunology, University of British Columbia, Vancouver, Canada *For correspondence: ibeatty@interchange.ubc.ca

[Abstract] The gene transfer agent (GTA) is a bacteriophage-like particle that transfers genomic DNA from a donor to a recipient bacterium. The Rhodobacter capsulatus GTA (RcGTA) was the first to be studied and this protocol has been optimized for RcGTA transduction, although it could be modified for other bacteria containing a GTA. The RcGTA transduction assay can be used to determine transduction efficiencies, to create gene knock-outs, or to create new strains by transferring alleles from one strain to another.

\section{Materials and Reagents}

1. RcGTA donor strain (e.g. R. capsulatus $Y 262$ or Riff ${ }^{R}$ strain)

2. Recipient strain (e.g. R. capsulatus DW5 [photosynthesis mutant] or Rif ${ }^{\mathrm{S}}$ strain to test the transfer of the Rif ${ }^{R}$ allele)

3. Potassium phosphate buffer

4. L-malic acid (Sigma-Aldrich, catalog number: 240176)

5. Thiamine hydrochloride (Sigma-Aldrich, catalog number: T1270)

6. G-buffer (filter sterilize) (see Recipes)

7. RCV broth/agar ${ }^{1}$ (see Recipes)

8. YPS broth/agar ${ }^{3}$ (autoclaved) (see Recipes)

\section{Equipment}

1. Variable temperature shaker for test tubes $\left(30-35^{\circ} \mathrm{C}\right)$

2. Anaerobic jars for photosynthetic growth (if using photosynthesis mutant for recipient)

3. Light box for photosynthetic growth

4. $30^{\circ} \mathrm{C}$ incubator

5. Test tubes

6. $17 \mathrm{ml}$ glass screwcap tubes

7. $10 \mathrm{ml}$ plastic culture tubes

8. Glass beads

9. $0.45 \mu \mathrm{m}$ pore-size filter 
10. $10 \mathrm{ml}$ syringe

\section{Procedure}

Day 1

1. Streak Rhodobacter capsulatus Y262 containing plasmid containing gene to be transferred (or other gene donor), and DW5 (or other desired recipient strain) on RCV agar plates with appropriate antibiotics.

2. Incubate plates aerobically at $30^{\circ} \mathrm{C}$ for 2 days (or until colonies form).

Day 3

3. In a $17 \mathrm{ml}$ screwcap tube (should contain sterile glass beads to help with mixing the cells during growth) inoculate $17 \mathrm{ml}$ of YPS broth (NO antibiotic) with Y262 (containing plasmid) from a single colony.

4. Grow photosynthetically at $30^{\circ} \mathrm{C}$ until culture is well into the stationary phase (cell density should be around 450-500 Klett units).

Day 4

5. In test tubes inoculate $7 \mathrm{ml} \mathrm{RCV}$ broth with $R$. capsulatus DW5 or recipient strain(s) from a single colony.

6. Incubate at $30^{\circ} \mathrm{C}$, shaking at 250 RPM for 2 days (cell density should be around $300-350$ Klett units).

Day 6

7. Spin down $7 \mathrm{ml}$ of DW5 and recipient cultures at $\sim 20,000 \times g(5,000 \mathrm{rpm}$ in a Beckman JA-20 rotor) for 5 min.

8. Decant and resuspend cell pellets in $3.5 \mathrm{ml} \mathrm{G}$-buffer.

9. Spin down $17 \mathrm{ml}$ of $\mathrm{Y} 262$ (plasmid) donor strain at $\sim 20,000 \times \mathrm{g}$ for $5 \mathrm{~min}$ to pellet most of the cells.

10. Filter the remaining culture supernatant with a $0.45 \mu \mathrm{m}$ pore-size filter into a sterile plastic (polystyrene) tube (not glass because it is suspected that RcGTA particles stick to glass).

11. Prepare the transduction mix in a $10 \mathrm{ml}$ plastic culture tube:

$0.1 \mathrm{ml}$ filtrate (donor)

$0.2 \mathrm{ml}$ recipient

$0.4 \mathrm{ml} \mathrm{G}$-buffer

$0.7 \mathrm{ml}$ total volume 
(Negative controls: 1 ) lacking the recipient and 2) lacking the RcGTA donor; positive control: DW5 with photosynthetically capable donor RcGTA).

12. Incubate the transduction mix for $1-1.5 \mathrm{~h}$ at $30-35^{\circ} \mathrm{C}$ with slow shaking (150 rpm).

13. Add $0.9 \mathrm{ml} \mathrm{RCV}$ broth to each tube and incubate for $3-4 \mathrm{~h}$ at $30-35^{\circ} \mathrm{C}$ with slow shaking ( 150 rpm).

14. Transfer transduced culture to a $1.7 \mathrm{ml}$ microcentrifuge tube and pellet cells at maximum rpm for $30 \mathrm{sec}$.

15. Decant the majority of the supernatant leaving about $50 \mu \mathrm{l}$.

16. Resuspend cells in remaining supernatant and spread cells on an agar plate appropriate for selection (for DW5 positive control may use YPS medium).

17. Incubate plates in conditions appropriate for selection for 3-4 days (for positive control, select for anaerobic photosynthetic growth).

18. Test colonies for desired insertion.

\section{$\underline{\text { Recipes }}$}

1. G-buffer (filter sterilize)

$10 \mathrm{mM} \quad$ Tris- $\mathrm{HCl}(\mathrm{pH} 7.8)$

$1 \mathrm{mM} \quad \mathrm{MgCl}_{2}$

$1 \mathrm{mM} \quad \mathrm{CaCl}_{2}$

$1 \mathrm{mM} \quad \mathrm{NaCl}$

$0.5 \mathrm{mg} / \mathrm{ml} \mathrm{BSA}$

2. RCV broth/agar (in $1 \mathrm{~L}$; autoclaved)

$4 \mathrm{~g} \mathrm{D}$, L-malic acid

$1 \mathrm{~g}\left(\mathrm{NH}_{4}\right)_{2} \mathrm{SO}_{4}$

$10 \mathrm{mM}$ potassium phosphate buffer

$200 \mathrm{mg} \mathrm{MgSO}{ }_{4} \cdot 7 \mathrm{H}_{2} \mathrm{O}$

$75 \mathrm{mg} \mathrm{CaCl} 2 \cdot 2 \mathrm{H}_{2} \mathrm{O}$

$12 \mathrm{mg} \mathrm{FeSO} \cdot \cdot 7 \mathrm{H}_{2} \mathrm{O}$

$20 \mathrm{mg} \mathrm{Na}{ }_{2}$ EDTA

$1 \mathrm{ml}$ trace element solution

$1 \mathrm{mg}$ thiamine hydrochloride

$\mathrm{pH}$ adjusted to 6.8 with $\mathrm{NaOH}$ before autoclaving

(For agar add $1.5 \%$ agar)

Trace element solution (in $250 \mathrm{ml} \mathrm{dH}_{2} \mathrm{O}$ )

$0.7 \mathrm{~g} \mathrm{H}_{3} \mathrm{BO}_{3}$

$398 \mathrm{mg} \mathrm{MnSO}{ }_{4} \cdot \mathrm{H}_{2} \mathrm{O}$ 
$188 \mathrm{mg} \mathrm{Na} 2 \mathrm{MoO}_{4} \cdot 2 \mathrm{H}_{2} \mathrm{O}$

$60 \mathrm{mg} \mathrm{ZnSO} \cdot 7 \mathrm{H}_{2} \mathrm{O}$

$10 \mathrm{mg} \mathrm{Cu}\left(\mathrm{NO}_{3}\right) \cdot 3 \mathrm{H}_{2} \mathrm{O}$

3. YPS broth/agar ${ }^{3}$ (autoclaved)

$0.3 \%$ Difco yeast extract

0.3\% Difco Bactopeptone

$2 \mathrm{mM} \mathrm{CaCl}_{2}$

$2 \mathrm{mM} \mathrm{MgSO}_{4}$

(For agar add $1.5 \%$ agar)

\section{Acknowledgments}

The development of this protocol was funded by a grant to J.T.B. from the Canadian Institutes of Health Research. This protocol was adapted from the assay developed by Solioz et al. (1975).

\section{References}

1. Beatty, J. T. and H. Gest (1981). Generation of succinyl-coenzyme A in photosynthetic bacteria. Arch Microbiol 129(5): 335-340.

2. Leung M. M., Brimacombe C. A., Spiegelman G. B., and Beatty J. T. (2012) The GtaR protein negatively regulates transcription of the gtaRl operon and modulates gene transfer agent (RcGTA) expression in Rhodobacter capsulatus. Mol Microbiol 83(4):75974.

3. Solioz, M., Yen, H. C. and Marris, B. (1975). Release and uptake of gene transfer agent by Rhodopseudomonas capsulata. J Bacteriol 123(2): 651-657.

4. Wall, J. D., Weaver, P. F. and Gest, H. (1975). Gene transfer agents, bacteriophages, and bacteriocins of Rhodopseudomonas capsulata. Arch Microbiol 105(3): 217-224. 